\title{
QUALIFICATION AND QUALITY IN THE THIRD SECTOR: EXPERIENCES IN TWO PORTUGUESE REGIONS
}

\author{
ANA RODRIGUES, PATRÍCIA ANTÓNIO, ANA CANTANTE, ALBERTO \\ BAPTISTA
}

\begin{abstract}
:
In most industrialized countries the 3rd sector has shown a significant growth, both in the number of organisations, and in the number and diversity of its intervention areas, which has allowed a greater visibility of the activities and services that it provides. In Portugal, there is a lack of national data on the way the organisations of this sector operate due to its heterogeneity in terms of juridical forms and organisational structures. The reality of the Portuguese third sector is characterized by a diversity of organisational models. There is a set of problems linked to the management and internal functioning of the organisations that form the third sector, which reduces the efficiency and the provision of quality services. The weaknesses of the sector may be tackled with a qualification support programme that promotes the development of skills in the third sector organisations, improving their performance quality and contributing to its sustainability.

The Project "Qualifying the 3rd sector" (Q3) is an intervention methodology for organizations in this sector, which seeks to develop individual skills, improving the quality of its provision and management effectiveness through participated and supported consulting and training processes. This project acts in the North, Centre, Alentejo and Algarve regions, involving 96 entities in the 3rd sector.

The aim of this study is to present the results of the project assessment in the intervened institutions in two regions of Portugal (North and Alentejo). A mixed approach that combines qualitative and quantitative methods was used. In-depth interviews were conducted with regional consultants teams (two project coordinators and 13 consultants), and a questionnaire survey was applied to board members and technical staff of the 47 intervened organizations in the two regions.
\end{abstract}

The results are varied in relation to the parameters in evaluation. The intervened institutions recognize the unquestionable contribution of this programme to the qualification of their human capital. The programme left relevant prints in the intervened organisations such as, the provision of management support tools, the rethinking of attitudes and behaviours, a greater accountability and an increase of knowledge as well as a higher efficiency and efficacy in the provision of services thus increasing their quality. Some reflections, although not intended to be generalized to all organizations in the sector, may be useful for a better understanding of their functioning and to establish itself as a tool to support a more professional and thus a more competitive management, are identified.

\section{Keywords:}

Qualification; Quality; Management; Third sector

JEL Classification: M00, L15, L31 


\section{Authors:}

ANA RODRIGUES, University of Trás-os-Montes and Alto Douro, Portugal, Email: anarodri@utad.pt PATRÍCIA ANTÓNIO, University of Trás-os-Montes and Alto Douro, Portugal, Email: pantonio@utad.pt ANA CANTANTE, University of Trás-os-Montes and Alto Douro, Portugal, Email: acordeiro@utad.pt ALBERTO BAPTISTA, University of Trás-os-Montes and Alto Douro, Portugal, Email: abaptist@utad.pt

\section{Citation:}

ANA RODRIGUES, PATRÍCIA ANTÓNIO, ANA CANTANTE, ALBERTO BAPTISTA (2015). Qualification and quality in the third sector: Experiences in two Portuguese regions. International Journal of Business and Management, Vol. III(3), pp. 58-84., 10.20472/BM.2015.3.3.005 


\section{Introduction}

Third sector organizations have shown an indisputable value in solving social problems that plague today's civil societies. Understanding the logic inherent to the multiplicity of organizations that comprise this sector is a key element to minimize its complexity. There is a great diversity of organizational structures, legal forms and management practices in these institutions. These factors limit the performance and development of these organizations and therefore requiring optimal management that is essential for the development of strategies to achieve organizational sustainability. Hence the importance and need for qualified professionals to work in this area through the development of multiple managerial, organizational and individual skills. The project qualify the third sector (Q3 project) aims to achieve this goal.

The Q3 project is a nationwide program that seeks to develop the skills of human resources and improve the management of the 3rd Sector organizations. It acts on the quality of their services and the effectiveness of management through participatory and sustained consulting and training processes. The Q3 has various fields of expertise in areas related to: Forms of organization and management; Value chain of services; Integration of ICT; Improvement of procedures aimed at quality certification; Development of internal skills (training and development for managers and specific training for employees); Implementation of inter-institutional cooperation models, among others.

This program is in its 3rd edition ${ }^{1}$, having qualified 96 organizations in four regions of Portugal (Norte, Center, Alentejo and Algarve). The intervention model advocates a set of phases and activities guided by principles of participation and sustainability. Figure 1 shows the number of phases associated with Q3 intervention.

\footnotetext{
${ }^{1}$ The Q3 Project is financed by the Operational Programme Human Potential (POPH) - Priority Axis 3, Intervention typology 3.1.2 - Training Programme - Action for entities of the Social Economy.
} 
Figure 1: Q3 General Plan of Activities

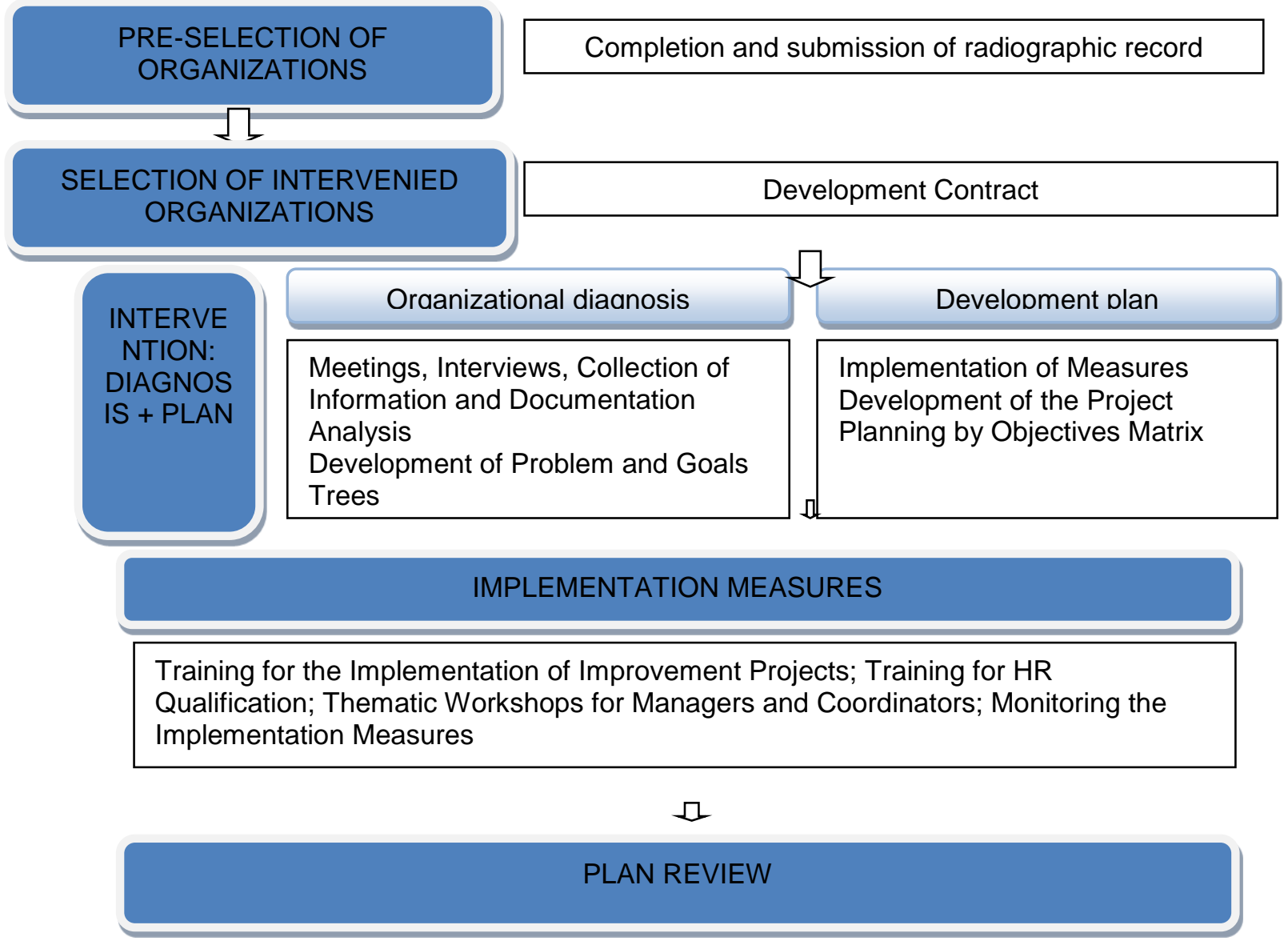

Source: Own elaboration

The promotion of Q3 is under the responsibility of three entities (Confederação Portuguesa das Coletividades de Cultura, Recreio e Desporto - CPCCRD; Federação Nacional de Cooperativas de Solidariedade social - FENACERCl; Federação Portuguesa de Associações de Desenvolvimento Local - MINHA TERRA), and three training entities (Associação Empresarial do Porto - AEP; Centro de Iniciativas Empresariais e sociais - IEBA; Associação IN LOCO). The monitoring and evaluation of the program is the responsibility of a public university in the Norte of Portugal (University of Tras-os-Montes and Alto Douro).

For each region a regional coordinator, which directs all activities in its region, was designated. Every organization is provided a liaison consultant (LC), which is responsible for all the aspects of the intervention. To assist the implementation of the Q3 project in each intervened organization a person, with many roles in the organization and holds knowledge and experience to ensure a successful implementation of the program, called internal facilitator (IF) is identified.

The main objective of this paper is to present the evaluation results of the project in Q3 intervened organizations in two regions of Portugal (Norte and Alentejo). The following specific aims were defined: a) characterize the intervened organizations; b) present the vision of the regional coordinators and LC; and c) analyzing the view of IF and board members of intervened organizations. 
This article, in addition to the introduction, has four points, namely: the second with a brief review of the literature, the third describing the methodological procedures, the fourth presents the results, and the latter a concluding note.

\section{Literature review}

\subsection{The Portuguese third sector}

In most industrialized countries a significant growth of what has been agreed to call "third sector" has been witnessed. This activity sector has several titles ranging from social economy, non-profit sector, non-governmental organizations and civil society. The Portuguese Constitution, referring to the economic and social organization of the country, identifies the coexistence of three sectors: the public sector, the private sector and the cooperative and social sector.

The designation 3rd sector is a term that by its scope and conceptual simplicity best describes the notion first discovered by the academics, then by the media and widely used by policy makers and the general public. The 3rd sector points to a concept next to the non-governmental sector which is distinct from commercial or the profit-making sector and public or government sector. It is actually the sector that occupies its own space, with a formal identity, between the public sector and the private business sector.

Douglas (1983) was one of the first authors to use the concept of 3rd sector and emphasizes two absolutely significant aspects of this terminology: (1) it is a relevant sector player, and (2) with defined borders but that is not isolated. Firstly, it is a sector with its own identity and a player at the same level as the state and the private business sector in terms of ownership of the means of production. The 3rd sector, in the author's opinion, is the best expression of the concept of freedom in that it assumes a collective rationality of volunteering, rather than what happens to the state, which although also has a collective rationality, it involves a coercion power that only the state can invoke through legislation. Both the State and the 3rd sector are distinct from the market in the sense that in the latter predominates an individual rationality and the identity lies in the exchange relations in the form of commercial transactions (Douglas, 1983: 27-28).

In addition to the recognition of an identity specific to the sector, Douglas believes that it is not isolated and is permeable to permanent contact with the other two sectors. Governments usually have something to say in almost all initiatives of the 3rd sector and often finance its organizations. Governments often use the institutions of the 3rd sector as agents to perform tasks that are those traditionally of the state. 3rd sector organizations are, in some cases, almost totally dependent on government funding; others have their own funds to start new tasks in order to promote the functions of the public sector. Many private sector companies create foundations with charitable purposes and others play themselves philanthropic tasks (Douglas, 1983: 14). 
If in terms of the contribution for the social organization and the economic activity the importance of the 3rd sector is neither negligible nor residual, from the point of view of the clarification of the concept, particularly in methodological terms, there are many existing conceptualizations.

Pestoff (1998), for example, states that the concept of a 3rd sector is a convention that summarizes a diverse set of formal organizations that are neither government agencies nor profitable companies, being therefore defined in relational terms by its position relatively to the other two sectors. The 3rd sector is distinguished from the state because it does not provide mandatory or public services, and differs from the market because it does not provide services with a profit end, and simultaneously it is distinct from the informal sector because it is formalized in organizations. This notion differs from Douglas to the extent that the latter incorporates in the 3rd sector volunteering and the informal economy. The author does not envisage the possibility of a fourth or fifth sector.

Different conceptualizations of the 3rd sector are especially needed for it to be recognized and made visible, by the other two sectors - a space and a identity that is already a reality - both in the world and in Portugal.

The most striking aspect of the growing importance of the 3rd sector mentioned by Santos (1999) is that this sector is emerging with equal vigour in peripheral and semiperipheral countries: "If in some of these countries such organizations resulted from the consolidation and sometimes the decline of new social movements, others, especially in the most peripheral, the outbreak of such organizations was due to changes in strategy of the most central countries in the field of international assistance, which began to be channelled primarily to non-state actors" (Santos, 1999:16).

From a theoretical point of view the conceptualization of the 3rd sector can be structured into two groups: the Anglo-Saxon and Continental Europe (Defourny and Develtere, 1999; Laville et al., 2000). From the analysis of these two conceptualizations results a different study functionality of the economic importance of the sector. In the Anglo-Saxon case, methodologically, the non-profit sector is thought of in terms of its contribution to social activities of the market or the private business sector. In the concept of continental Europe, the 3rd sector is understood as a social economy system in which the 3rd sector is an alternative to the market with a quantifiable contribution.

The empirical approach of the Anglo-Saxon conceptualization applied to the Portuguese 3rd sector is that of the Comparative Non-profit Sector Project, undertaken by the Johns Hopkins University, in partnership with the Catholic University of Porto with data of 2005. More recently, in 2012, the National Statistics Institute (INE) published the Social Economy Satellite Account data (CSES), using as reference the Handbook on Nonprofit Organizations in the System of National Accounts (UNSD, 2003), developed by the Center for Civil Society Studies at Johns 
Hopkins and the United Nations Statistics Division, in cooperation with António Sérgio Cooperative for Social Economy.

To create the CSES in Portugal, the operational definition considered was the one defined by the Centre International de Recherches et d'Information sur I'Economie Publique, Sociale et Coopérative: "Set of private companies formally organized, with decision autonomy and freedom of membership, created to meet the needs of its members through the market by producing goods and services, ensuring funding and in which any distribution of profits or surpluses among its members as well as decision-making, are not linked directly to capital or each member of financial contribution, with one vote for each of them. The Social Economy also brings together those private entities formally organized with autonomy of decision and freedom of membership that produce non-market services to households, whose surpluses, if any, can not be appropriated by the economic agents that create, control or finance them" (CIRIEC; N CESE/COMM/05/2005).

The characterization of the Social Economy in Portugal was based on the analysis by type of activity, the number of entities (universe) and macroeconomic aggregates of Organizations of the Social Economy (OES). The main conclusions ${ }^{2}$ we intend to highlight are:

- In terms of the relative size of the sector in 2010, the Gross Value Added (GVA) of the Social Economy represented $2,8 \%$ of the national total GVA and 5,5\% paid employment (full-time equivalent - FTE).

- The average payment (by FTE) in the OES corresponded to a $83,1 \%$ of the national average, showing, however a significant dispersion.

- From the 55383 unities considered, the colectivities and other OES represented $94,0 \%$, being responsible for $54,1 \%$ of the GVA and $64,9 \%$ of the employment (paid FTE). The cooperatives constituted the second group of OES with the largest relative weight, in unit number terms of GVA and payments.

- Close to half $(48,4 \%)$ of the OES operated in activities of culture, sports and recreation, but its contribution in terms of GVA and paid employment (FTE) was relatively low (respectively, $6,8 \%$ and $5,4 \%$ );

- Social services created $41,3 \%$ of GVA of all OES, being responsible for $48,6 \%$ of paid employment (FTE);

- The resources of the OES were mainly created by production $(62,8 \%)$ and by other current transferences and other production subsidies (23,8\%). The OES expenses consisted, mainly on intermediate consumption $(31,4 \%)$, wages $(26,8 \%)$ and social transferences $(24,3 \%)$;

- In 2010, there were 5022 Social Solidarity Private Institutions (IPSS). These represented $50,1 \%$ of GVA, $42,6 \%$ of wages and $38,2 \%$ of the net financing needs of the Social Economy.

The findings on the social economy in Portugal clearly point to the recognition of the economic interest that the 3rd sector has and to a relation with the public sector in

${ }^{2}$ Retrieved from www.cases.pt/atividades/contasatelitees, in July 2014. 
terms of an efficient delegation of functions. Not only the contribution to the GVA and paid employment is more significant than that of many subsectors of the private business sector as state funding is only $23.8 \%$ of the resources managed by the $3 \mathrm{rd}$ sector organizations.

Finally, we do not identify here the findings of the Johns Hopkins project / Catholic University because it does not add updated data to the conclusions of the Social Economy Satellite Account. However we highlight the challenges that the study pointed to the 3rd sector in Portugal (Franco, Sokolowski et al., 2005):

- Increase public awareness on this sector;

- Change the legal framework, systematizing the different legal forms and improving the tax treatment of these organizations;

- Qualify the sector's management skills;

- Improve the relationship between the state and non-profit organizations.

In conclusion the 3rd sector has an economically recognized vitality and a very significant importance in the social organization of Portugal. The urge in facing the sector's challenges is merely the recognition of the strength of its identity.

\subsection{Quality e qualification in the third sector}

The quality is increasingly at the centre of the new economic and social environment and organizations need to demonstrate that they offer a quality service. Despite the motivational commitment of the 3rd sector to quality being intrinsically linked to the reasons of its genesis, the formal tools that ensure and demonstrate the quality of services have become, in the last decade, massively important.

An example of this growing demand for performance monitoring and evaluation of any organization and also those of the 3rd sector are management normative references ISO $(90001 ; 2000 ; 26000)$ and SA $(8000)$. The certification of the quality of services is a social responsibility of any organization. The ISO 9000-1, for example, defines quality as "the totality of characteristics of an entity that gives it the ability to satisfy stated and implied needs." And adds that quality is defined as "adequacy to the use or purpose" "customer satisfaction" and even "conformity to the requirements."

Thus, quality is strongly linked to market rules and therefore the same quality certification standards will be required to the 3rd sector as any traditional organization of the lucrative private sector. In fact, the innovation capacity assigned to the 3rd sector has enabled it to introduce new products or a new quality of products, new organizational methods, new production factors, new market relations and new entrepreneurial forms (Defourny, 2001; Horn, 2003; Lévesque, 2005 and 2006; Almeida, 2007). This capability results from the peculiarities inherent to the 3rd sector namely local proximity and the strong participation of stakeholders in providing services and promoting new forms of intervention in the organization's mission. 
In addition to this singularity, the nature of trade relations and supply of services differs to that of the lucrative private sector. Hence, the beneficiaries generally do not pay the market price of the service and therefore revenues heavily depend on the relations with donors and other stakeholders, pointing to other quality requirements beyond mere customer satisfaction.

However, there are other characteristics that point to real limitations on the ability of the 3rd sector to innovate with quality. The lack of human resources, low-skilled workers and the lack of dynamism of the leaders are increasingly identified as factors that need to be tackled (GEP/MTSS, 2008).

In fact, insufficient professionalization of human resources, especially with the lack of specific degrees directed towards the employment needs of the 3rd sector (Rebola, 2004: 113) and the low supply of skilled labour are factors identified as strong bottlenecks to the sectors' current quality requirements. In this context, it stands out as a strong weakness of the 3rd sector, the lack of skills in the management of the organizations (Hespanha et al., 2000). The consequences of this constraint at the management level is very relevant, since the leadership tends to be quite centred on the figure of the leader of the organizations of the 3rd sector (Hespanha et al., 2000: 178).

In fact, studies show that the academic qualification of human resources in the 3rd sector, in Portugal, is deficient in training in the area of management. The typical profile of the graduates working in the sector has a degree in Sociology, Psychology, Modern Languages and Literature or European Studies (Parente, C., 2012).

This is particularly relevant as the quality assessment models identify leadership, process management, management of human resources and a focus on results, among others, as key requirements for the excellence of an organization (European Foundation for Quality Management, 2012).

The European Foundation for Quality Management, supported by the European Commission in the European Quality Promotion Policy, created the EFQM Excellence Model, serving as a reference to quality certification by the Social Security in Portugal basically says that:

Excellent results with respect to Performance, Customers, People and Society are achieved through Leadership driving Planning and Strategy, People, Partnerships and Processes.

Quality excellence is defined in this model as: Excellent Organisations achieve and sustain outstanding levels of performance that meet or exceed the expectations of all their stakeholders (EFQM, 2015).

In a context of economic crisis and state decline in the supply of traditional goods and services of public interest, not only adds to the need for more 3rd sector organizations, but above all the need to ensure the sustainable development of the organizations that already operate in this sector. 


\section{Methodology}

This paper presents the final evaluation of Q3 program's results in two Portuguese regions: Norte and Alentejo. In this study we used a mixed research approach, of quantitative and qualitative methodological perspectives.

It started with the organization of a focus group with the regional coordinator and LC. The interview was carried out using a structured script, in order to control the conduct of the actions, the overall quality of the project implementation and results and the changes introduced in organizations.

In a second stage, the information was gathered through inquiry by questionnaire sent by e-mail address to all intervened organizations. This took into account the problems identified, the measures implemented and the results obtained.

In the following table we present the various methodological aspects, associated to the monitoring and assessment Q3 plan, undertaken in the two studied regions.

Table 1: Final Evaluation Methodological Record

\begin{tabular}{|c|c|c|}
\hline & Norte & Alentejo \\
\hline $\begin{array}{l}\text { Methodological } \\
\text { approach }\end{array}$ & $\begin{array}{l}\text { - Qualitative } \\
\text { - Quantitative }\end{array}$ & \\
\hline $\begin{array}{l}\text { Level of analysis | } \\
\text { Population } \\
\text { Respondents }\end{array}$ & $\begin{array}{l}\text { Organizational: } 26 \text { intervened } \\
\text { organizations } \\
\text { - Individual: Regional Coordinator } \\
\text { and } 18 \text { liaison consultants }\end{array}$ & $\begin{array}{l}\text { Organizational: } 21 \text { intervened } \\
\text { organizations } \\
\text { - Individual: Regional coordinator } \\
\text { and } 5 \text { liaison consultants }\end{array}$ \\
\hline Technique used & 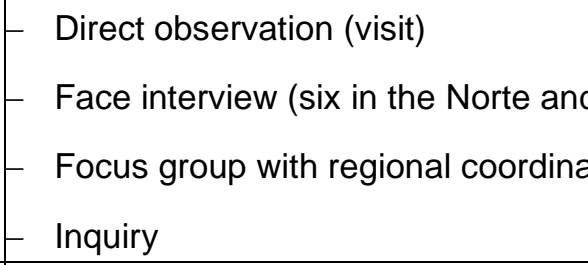 & $\begin{array}{l}\text { six in Alentejo) } \\
\text { tors and liaison Consultants }\end{array}$ \\
\hline Instruments applied & $\begin{array}{l}\text { - Structured interview Script } \\
- \text { Questionnaire }\end{array}$ & \\
\hline Period of application & $\begin{array}{l}\text { June } 23,2014 \text { and } 1 \text { and } 2 \text { July } \\
2014\end{array}$ & - 2 and 3 July 2014 \\
\hline Response Rate & $\begin{array}{l}\text { Number of organizations: } 24 \\
\text { (92\%); Regional Coordinator: } 1 \\
(100 \%) \text {; Liaison consultants: } 8 \\
\text { (44.44\%); }\end{array}$ & $\begin{array}{l}\text { Number of organizations: } 19 \\
(90.5 \%) \\
\text { Regional Coordinator: } 1(100 \%) \\
\text { Liaison Consultants: } 5(100 \%)\end{array}$ \\
\hline
\end{tabular}

Source: Own elaboration 
The analysis and processing of qualitative data was based on content analysis of the interviews conducted with the $\mathrm{FI}$ intervened organizations as well as the regional coordinators and LC. For the analysis and processing of quantitative data, we resorted to the statistical program SPSS 20.0 (Statistical Package for Social Sciences) for Windows. The data were analyzed using simple and basic statistical procedures, such as frame frequency distribution, and more complex procedures, depending on the type of issues involved.

\section{Results}

\subsection{Characterization of the intervened organizations}

This work focuses on the evaluation of the Q3 project in two regions of Portugal: Norte and Alentejo. Then the profile of disturbed organizations and their major problems is analyzed.

\section{Profile of the intervened organizations}

Considering the existing typologies in the intervened organizations, table 2 lists the number of institutions and beneficiaries for each region.

Table 2: Third sector Types of Organizations and beneficiaries

\begin{tabular}{|c|c|c|c|}
\hline $\begin{array}{l}\text { Organizations } \\
\text { Types }\end{array}$ & Region & $\begin{array}{l}\text { Number of } \\
\text { organizations }\end{array}$ & Type of beneficiaries \\
\hline \multirow{2}{*}{$\begin{array}{l}\text { Local development } \\
\text { associations }\end{array}$} & Norte & 6 & \multirow{2}{*}{$\begin{array}{l}\text { 3rd sector organizations, public } \\
\text { organizations, firms and } \\
\text { entrepreneurs, children, youth, adults, } \\
\text { seniors, family and community, } \\
\text { unemployed, students / trainees. }\end{array}$} \\
\hline & Alentejo & 3 & \\
\hline \multirow{2}{*}{$\begin{array}{l}\text { Organizations } \\
\text { supporting people } \\
\text { with disabilities }\end{array}$} & Norte & 3 & \multirow{2}{*}{$\begin{array}{l}\text { People with disabilities and / or mental } \\
\text { illness, children at social risk or } \\
\text { serious risk of development, family, } \\
\text { community and public authorities. }\end{array}$} \\
\hline & Alentejo & 4 & \\
\hline \multirow[b]{2}{*}{$\begin{array}{l}\text { Social service } \\
\text { organizations } \\
\text { (including } \\
\text { organizations that } \\
\text { are dedicated to } \\
\text { social support, } \\
\text { especially the elderly } \\
\text { and children) }\end{array}$} & Norte & 14 & \multirow[b]{2}{*}{$\begin{array}{l}\text { Children, youth, adults, seniors, } \\
\text { disabled, convalescing patients, drug } \\
\text { addicts, minorities, family and } \\
\text { community, unemployed, } \\
\text { students/trainees, public } \\
\text { organizations, firms, organizations of } \\
\text { the 3rd sector and entrepreneurs. }\end{array}$} \\
\hline & Alentejo & 11 & \\
\hline Collectivities (who & Norte & 3 & Children, youth, adults, seniors, family \\
\hline
\end{tabular}




\begin{tabular}{l|l|l|l}
\hline $\begin{array}{l}\text { are dedicated to } \\
\text { recreational, } \\
\text { sporting, cultural and } \\
\text { artistic activities) }\end{array}$ & Alentejo & 3 & $\begin{array}{l}\text { and community and public } \\
\text { organizations. }\end{array}$ \\
& Norte & 26 & \\
\hline Total & Alentejo & 21 & \\
\hline
\end{tabular}

Source: Own elaboration

The intervened organizations exhibit some diversity in the 3rd sector's context, representing different realities.

Considering longevity, Northern organizations range from five to a maximum of 93 years. Being the average age for all organizations intervened in this region 32.2 years. In Alentejo, very diverse organizations were intervened, ranging from those undergoing their first steps in the association (minimum age $=3$ years) to centennial organizations, one of them overcoming 5 centuries of experience (maximum age = 513 years). The average age of the institutions intervened in this region is 56.6 years. Table 3 presents the human resources structure for the two regions under review.

Table 3: Structure of human resources in Norte and Alentejo

\begin{tabular}{|c|c|c|c|}
\hline \multicolumn{2}{|c|}{ Characterization variables } & Region & Total Values \\
\hline \multirow{2}{*}{\multicolumn{2}{|c|}{ Dimension / Total employees }} & Norte & 1156 \\
\hline & & Alentejo & 1110 \\
\hline \multirow{2}{*}{\multicolumn{2}{|c|}{ Number of volunteers }} & Norte & 175 \\
\hline & & Alentejo & 199 \\
\hline \multirow{6}{*}{ 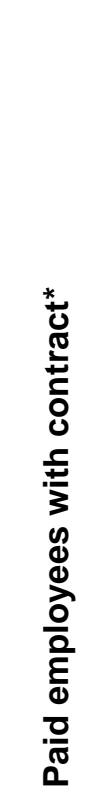 } & \multirow[t]{2}{*}{ Number ** } & Norte & 981 \\
\hline & & Alentejo & 818 \\
\hline & \multirow[t]{2}{*}{ Gender ** } & Norte & $\begin{array}{l}191 \text { men } \\
794 \text { women }\end{array}$ \\
\hline & & Alentejo & $\begin{array}{l}106 \text { men } \\
667 \text { women }\end{array}$ \\
\hline & \multirow[t]{2}{*}{$\underset{\star \star}{\text { Academic Qualifications }}$} & Norte & $\begin{array}{l}\text { Up to 6th year (115); } \\
\text { 9th year (285); } \\
\text { 12th year (209); } \\
\text { High education (375) }\end{array}$ \\
\hline & & Alentejo & $\begin{array}{l}\text { Up to 6th year (167); } \\
\text { 9th year (186); }\end{array}$ \\
\hline
\end{tabular}




\begin{tabular}{|c|c|c|}
\hline & & $\begin{array}{l}\text { 12th year (157); } \\
\text { High education (212) }\end{array}$ \\
\hline \multirow[t]{2}{*}{ Age Groups ** } & Norte & $\begin{array}{l}19-30(121) \\
31-40(314) \\
41-50(212) \\
51-65(133) \\
>66(6)\end{array}$ \\
\hline & Alentejo & $\begin{array}{l}19-30(179) \\
31-40(213) \\
41-50(178) \\
51-65(165) \\
>66(7)\end{array}$ \\
\hline
\end{tabular}

* It includes the following categories: Contract-Employees; Self-Employed; Trainee and POC's Inclusion Employment Agreement; ** The differences between the total number of paid employees and their total amounts in the respective categories (gender, academic qualifications and age groups) are due, on the one hand, to no answers and, on the other hand, to different values found in the documents we examined (radiographic records and contents of interest letters).

Source: Own elaboration

In the 26 Northern region intervened organizations, regarding the structure of human resources, the following results were obtained:

- The total number of reviewers (both remunerated and volunteers) has an average value of 46.24, ranging from six to 216 . Typically 3rd sector's micro and small institutions, taking into account the (criterion) number of existing collaborators. Only two organizations have over 101 employees and can be classified as medium-sized (104 to 216 employees each);

- Gender analysis of paid employees shows a clear dominance of females (81\%);

- Qualifications: Employees paid under contract with high education represent $38.1 \%$ of the total. Of the remainder, only $12 \%$ have schooling up to the 6 th year; $29 \%$ have education up to 9 th grade and $21 \%$ to the 12 th year.

- Age groups: Employees of organizations intervened in this region are, in general, relatively young. The most represented age group is from 31 to 40 years, with $40 \%$, followed by the $41-50$ range with $27 \%$ of employees. $15 \%$ of the employees belong to the age group from 19 to 30 years and $20 \%$ of the employees have between 51 and 65 years, with six employees aged over 65 .

Regarding the Alentejo region, the 21 organizations that were subject to Q3 intervention have the following characteristics in terms of human resources structure:

- The total number of employees has an average value of about 53, ranging between 10 and 124 . It is found that $50 \%$ of organizations are3rd sector's micro 
institutions. Within the remaining 50\%, six organizations hold between 51 and 100 employees (small organizations) and four over 100 employees and can be classified as medium;

- The distribution between the sexes (paid employees) shows a female gender domain in all organizations (86.3\%);

- The qualifications have a relatively uniform distribution through the four levels considered ( $\leq 6$ years: $23 \%$; $\leq 9$ years: $26 \%$; $\leq 12$ year: $22 \%$, High education: $29 \%$ ), showing a very comprehensive and egalitarian character before this characteristic of its employees. Since the vast majority are IPSS who develop activities of social support, alongside the need for specialized technical staff, who are senior, there are also needs in terms of the direct caregivers (examples: helpers homes, kitchen staff, etc.).

- The age groups present, once again, a relatively uniform distribution among the top four echelons considered. The last echelon being almost residual (19-30 years: 24\%; 31-40 years: 29\%; $41-50$ years: $24 \%$; $51-65$ years: $22 \%$;> 65 years: $1 \%$ ), with only seven employees over 65 years.

\section{Main problems of the intervened organizations}

The completion of the organizational diagnosis is one of the core activities of the intervention of the Q3 model, and should receive special attention. Carrying out a proper diagnosis is vital to defining measures adjusted to problem solving and the success of the intervention. Given this phase's critical importance, it is essential to refer to those with knowledge of the reality in question. The maximum participation of all organizations intervened in the survey of existing problems is required.

The level of participation and involvement of members of the organizations in the diagnostic development process is high. This is extremely important as it reveals the critical role that the participation of the institutions elements plays in the success of Q3 methodology, contributing to later stages minimized margin of error. In each organization, in addition to a general session, were interviewed leaders, paid employees and volunteers. In smaller organizations, the percentage of respondents individually exceeded $80 \%$ in both regions. However, as the size of the institutions increases, it tends to decrease the percentage of interviewed elements.

Interviews exposed a wide range of problems in each organization. These can be aggregated into categories, according to key themes: sustainability; positioning in the territory; internal organization / organizational performance; satisfaction / communication, quality and human resources management (Table 5).

Table 5: Main key issues by thematic area

Key Issues by thematic areas
No. of organizations and examples of problems identified

Norte

Alentejo 


\begin{tabular}{|c|c|c|}
\hline Sustainability & $\begin{array}{l}12 \\
\text { "Difficulty to ensure sustainable } \\
\text { growth of the organization" } \\
\text { "Conditioned growth and } \\
\text { sustainability" }\end{array}$ & $\begin{array}{l}13 \\
\text { "Limited financial resources" } \\
\text { "Inefficient Resources" } \\
\text { "Difficulties in obtaining support" }\end{array}$ \\
\hline $\begin{array}{l}\text { Positioning within the } \\
\text { territory }\end{array}$ & $\begin{array}{l}3 \\
\text { "Difficulty in positioning within the } \\
\text { territory and future challenges" } \\
\text { "Poor participation of the universe } \\
\text { of associates" }\end{array}$ & 0 \\
\hline $\begin{array}{l}\text { Internal } \\
\text { organization/organizational } \\
\text { performance }\end{array}$ & $\begin{array}{l}6 \\
\text { "Insufficient organizational } \\
\text { performance" } \\
\text { "operating deficits" } \\
\text { "global efficacy failure" }\end{array}$ & $\begin{array}{l}21 \\
\text { "Insufficient information to } \\
\text { support management" } \\
\text { "Internal organization difficulties" } \\
\text { "Ineffective organization of } \\
\text { documentation" }\end{array}$ \\
\hline $\begin{array}{l}\text { Internal and external } \\
\text { communication }\end{array}$ & $\begin{array}{l}2 \\
\text { "Low level of internal and external } \\
\text { satisfaction" } \\
\text { "Image of the institution" }\end{array}$ & $\begin{array}{l}18 \\
\text { "Little involvement with the local } \\
\text { community" } \\
\text { "barely functional internal } \\
\text { communication" } \\
\text { "Poorly articulated external } \\
\text { communication" }\end{array}$ \\
\hline Quality & $\begin{array}{l}4 \\
\text { "Deficit quality of answers" } \\
\text { "Dissatisfaction with the quality of } \\
\text { service" } \\
\text { "Non-compliance with the } \\
\text { requirements of supervisory } \\
\text { organization (Social Security)" }\end{array}$ & $\begin{array}{l}2 \\
\text { "Service low productivity in terms } \\
\text { of quality" } \\
\text { "Future existence of quality } \\
\text { certification by ISO standards" }\end{array}$ \\
\hline HR management & 0 & $\begin{array}{l}19 \\
\text { "HR Performance short of } \\
\text { expectations" } \\
\text { "Skill deficit of collaborators" }\end{array}$ \\
\hline
\end{tabular}

Source: Own elaboration

By observing Table 5, we recognize that in the Norte, many organizations (12) reveal sustainability problems, following internal organization and organizational performance issues (6). Four organizations revealed problems related to services quality deficits and only three showed constraints due to territory positioning.

In the Alentejo, we found that a significant proportion of organizations presents problems related to internal organization, communication / relationship (internal and 
external) and human resources management. Thirteen organizations show financial sustainability problems and two quality issues.

\subsection{The vision of regional coordinators and LC}

The role of regional coordinators in the success of the program is critical, since it is up to them all responsibility to coordinate, supervise and participate in the process of recruitment and selection of organizations. After choosing the organizations, the responsibility for implementation is transferred to the LC that establish the link between the various program actors articulating training needs with getting the appropriate trainers. As such, the sensitivity they develop over the implementation of the program is of substantial importance for the valuable contact that their job gives them.

The vision of regional coordinators and LC was obtained by conducting a focus group, in which were addressed issues related to: the context of each organization; the program implementation process; the intervention time; the results of participating in the program and the future prospects for Q3 (including suggestions for improvement and detection of problems and difficulties in its application).

Table 6: Most important aspects indicated by these elements

\begin{tabular}{|c|c|c|}
\hline Analysis factor & Norte & Alentejo \\
\hline Context & $\begin{array}{l}\text { The influence of the environment is } \\
\text { recognized. Training is directed to the } \\
\text { immediate needs of the organizations } \\
\text { and not to global and continuity } \\
\text { scenarios: "Sometimes we feel we are } \\
\text { giving them the fish and not teaching } \\
\text { them how to fish." }\end{array}$ & $\begin{array}{l}\text { The context does not interfere with } \\
\text { the implementation of Q3. }\end{array}$ \\
\hline Intervention time & $\begin{array}{l}\text { The opinion of respondents points to the } \\
\text { need to adapt the intervention time to } \\
\text { the size of the organization: "What does } \\
\text { not make sense is that the hours are the } \\
\text { same regardless of the size of the } \\
\text { organizations." }\end{array}$ & $\begin{array}{l}\text { For this analysis factor responses } \\
\text { are somewhat ambiguous, divided } \\
\text { between excess and lack of time, } \\
\text { relating directly to the size of the } \\
\text { organization. }\end{array}$ \\
\hline $\begin{array}{l}\text { Implementation } \\
\text { Process }\end{array}$ & $\begin{array}{l}\text { The vision of respondents about the } \\
\text { process is very positive, considering that } \\
\text { Q3 methodology is appropriate to } \\
\text { program objectives, and the more } \\
\text { successful, the greater the commitment } \\
\text { of the organization's employees. }\end{array}$ & $\begin{array}{l}\text { The greatest difficulties in } \\
\text { implementing the process have } \\
\text { taken place in the younger } \\
\text { organizations, and are due mainly } \\
\text { to the shortage of time of the } \\
\text { technical staff and the fact that the } \\
\text { formation focus on a small group of } \\
\text { trainees. }\end{array}$ \\
\hline $\begin{array}{l}\text { Degree } \\
\text { involvement }\end{array}$ & $\begin{array}{l}\text { The total availability and degree of } \\
\text { involvement of managers and } \\
\text { employees is crucial to the success of }\end{array}$ & $\begin{array}{l}\text { It is recognized as very positive the } \\
\text { interest shown by the management } \\
\text { in adopting the process; however, }\end{array}$ \\
\hline
\end{tabular}




\begin{tabular}{|c|c|c|}
\hline & $\begin{array}{l}\text { the measures, reaching to say that the } \\
\text { role of leaders of the organizations is of } \\
\text { utmost importance: "(...) when we } \\
\text { cannot guarantee that our interlocutor is } \\
\text { the chief, things work badly. (...) It is } \\
\text { crucial that the caller is who has the } \\
\text { power to make everything work. " } \\
\text { The involvement of employees is always } \\
\text { lower in early stages of the intervention, } \\
\text { but quickly surpasses this problems, } \\
\text { with the result that the process runs } \\
\text { smoothly. }\end{array}$ & $\begin{array}{l}\text { most ultimately delegate the } \\
\text { implementation of the same in } \\
\text { middle management, in itself } \\
\text { overworked: "(...) the problem is not } \\
\text { in the degree of commitment of the } \\
\text { managements (...); the problem is } \\
\text { that they expect that the technical } \\
\text { staff answers to everything and } \\
\text { they already have a lot to do." } \\
\text { With regard to the involvement of } \\
\text { employees the greatest difficulties } \\
\text { arise in smaller organizations for } \\
\text { the training leads to greater } \\
\text { individual workload. }\end{array}$ \\
\hline Strengths & $\begin{array}{l}\text { The adaptability of training measures to } \\
\text { the real needs of organizations is one of } \\
\text { the highlights reported by respondents. } \\
\text { They consider that this is the main } \\
\text { reason for the high motivation of the } \\
\text { institutions and their employees to } \\
\text { participate in the program. }\end{array}$ & $\begin{array}{l}\text { The fact that organizations are the } \\
\text { ones that identify the problems is } \\
\text { one of the enhancements made by } \\
\text { the consultants in this region, "(...) } \\
\text { was everything always worked } \\
\text { together." }\end{array}$ \\
\hline Weaknesses & $\begin{array}{l}\text { The most enhanced point is the large } \\
\text { bureaucratic burden associated with the } \\
\text { program. On the other hand, it is } \\
\text { concerning that the cross-training does } \\
\text { not apply to all institutions and that } \\
\text { when forced to do it, the organizations } \\
\text { discourage feeling that they're being } \\
\text { forced to do something that will not bring } \\
\text { them benefits. }\end{array}$ & $\begin{array}{l}\text { It's been mentioned excessive } \\
\text { bureaucracy and the inadequacy of } \\
\text { cross training as the main } \\
\text { disadvantages of the program: } \\
\text { "Organizations do not accept when } \\
\text { we present the problems (...)". }\end{array}$ \\
\hline Created dynamics & $\begin{array}{l}\text { The view is that the dynamics created } \\
\text { depend more on the organizations than } \\
\text { on the methodology of Q3. The program } \\
\text { detects needs of institutions hitherto } \\
\text { unknown and that allow them to improve } \\
\text { procedures. However, the maintenance } \\
\text { of these measures is always dependent } \\
\text { on the entity's commitment: "Even when } \\
\text { things do not go well, the Q3 always } \\
\text { adds something; turns out to be } \\
\text { valuable in some way (...) turns out to } \\
\text { be transformative." }\end{array}$ & $\begin{array}{l}\text { The actions generated significant } \\
\text { dynamic in the institutions by } \\
\text { solving the existing problems. } \\
\text { Some formations have more impact } \\
\text { than others for allowing a change } \\
\text { of immediate behaviour. }\end{array}$ \\
\hline Outcomes & $\begin{array}{l}\text { Generally the respondents say they are } \\
\text { satisfied with the results achieved } \\
\text { against expectations created, not only } \\
\text { for them but also by the organizations } \\
\text { themselves. } \\
\text { It is noted that the relationship that is } \\
\text { developed between teams of } \\
\text { consultants and organizations, whether }\end{array}$ & $\begin{array}{l}\text { The results are considered as very } \\
\text { positive, and in some organizations } \\
\text { "largely exceeded expectations." } \\
\text { Some organizations are more } \\
\text { reluctant to express an opinion on } \\
\text { the results, because they } \\
\text { understand that there is need for } \\
\text { more learning and those results will }\end{array}$ \\
\hline
\end{tabular}




\begin{tabular}{ll|l} 
personal or professional, also & be put in place later, making it \\
contributes to the success of the & difficult to real perception of the \\
program: "I had a demanding entity, & program results. However point out \\
which meant that at the outset, I also & $\begin{array}{l}\text { that "there is an organization before } \\
\text { and after the Q3". }\end{array}$ \\
had this stance." &
\end{tabular}

Source: Own elaboration

In short, the perception of the LC and regional coordinators is that the Q3 fulfilled, and in many cases, exceeded the expectations with which the players started the whole process. This does not preclude that less favorable aspects of the program were singled out. Those aspects reinforce the need to eliminate some cross training in organizations that do not require them, which would create the opportunity for other more necessary training. This is a recurring claim and it is due to the fact that the intervention time is often referred to as insufficient.

As improvement measures, the LC highlight two fundamental aspects that relate to the importance of better publicizing the program and creating a post Q3 intervention support line. Added to these measures, others have been identified as likely to contribute to the future success of the program, such as increasing the time allotted for the diagnostic phase; sharing of experiences among the different teams of consultants; ability to create flexibility in the hours for the training, etc.

In general, the LC and the coordinators of both regions consider that the Q3 is an added value to the institutions of the 3rd sector, contributing to greater internal efficiency and a substantial improvement in the provision of services to the community.

\subsection{The vision of the board members and technical staff of the intervened organizations}

We approached the view of managers and technical staff of intervened organizations in the Q3 project. For the Norte, of the 26 intervened organizations, two did not respond to the inquiry. In Alentejo, a total of 21 gave 19 valid responses. Next we present the main results of the inquiry, taking into account certain dimensions under review.

\section{How organizations come to know the Q3 project}

For both regions, the main effort of project dissemination was made by the three promoters along its associates. Other sources include those responsible for the execution of the project on the field, technical directions or teams who have intervened in previous editions and also participation of the organization's technical staff in workshops held in previous editions. Personal contacts with other institutions that already knew the program were also a source used.

\section{Prior knowledge of the Project}

11 institutions of the Norte had some prior knowledge of the Q3 project through indications of the promoter or institutions who participated in previous editions. In the 
Alentejo, eight organizations reported having prior knowledge of the existence of Q3, because they had participated in previous editions (4), because they knew of similar interventions in other organizations of the 3rd sector (3), and from meetings at the promoter (1).

\section{Participation in previous editions}

In the Norte region, of the 24 organizations that replied to the questionnaire, 23 organizations had never participated in previous editions of the Q3 project. For the Alentejo region, four had already participated. In the case of organizations that repeated their participation in Q3, they did so because, apart from the fact of considering the previous experience as very positive, also felt the need to continue the work already done, and to have more different training.

\section{Reasons for the involvement of organizations in Q3 project}

Organizations were asked about the reasons / motivations that led them to participate in the Q3 project. Each entity had the opportunity to submit up to three reasons (Table 7).

Table 7: Reasons for participating on the Q3 project

\begin{tabular}{|c|c|}
\hline Norte & Alentejo \\
\hline $\begin{array}{l}\text { - Strong desire to have access to } \\
\text { training initiatives and knowledge / } \\
\text { skills to contribute to the qualification } \\
\text { of institutions and their employees and } \\
\text { directors; } \\
\text { - Concern for quality issues, } \\
\text { specifically with regard to aid in } \\
\text { certification processes and } \\
\text { implementation of quality systems; } \\
\text { - The opportunity to carry out an } \\
\text { organizational diagnosis and } \\
\text { development plan, through an outside } \\
\text { look; } \\
\text { - Improving internal organizational } \\
\text { processes; } \\
\text { - Ability to improve outcomes; } \\
\text { - Assistance in communication } \\
\text { processes; } \\
\text { - No charge for the training; } \\
\text { - Program Flexibility; } \\
\text { - Investment in other solutions; }\end{array}$ & $\begin{array}{l}\text { - The possibility of training, reinforced by the need to: } \\
\text { increase the level of theoretical / practical knowledge of } \\
\text { professionals, conduct work station oriented training and } \\
\text { adapted to the reality and professional practice of the } \\
\text { institution, and to develop training that is not limited to the } \\
\text { national formations catalogue (ex.: "To be a training tailored } \\
\text { to the organization; in the disability area there is nothing and } \\
\text { I is the } 1 \text { st time we met a number of specific training } \\
\text { measures for the disabled"); } \\
\text { - The possibility of obtaining a targeted support for specific } \\
\text { needs of organizations as, for example, in terms of } \\
\text { procedures and operation, communication, modernization, } \\
\text { visibility, institutional improvement and strategic planning; } \\
\text { - Improving the organization's quality. The need to improve } \\
\text { the quality of services provided by the entity, together with } \\
\text { the need of the respective certification; } \\
\text { - The recognition of positive aspects in Q3, such as being } \\
\text { an innovative design, well organized, with a well-tested and } \\
\text { proven methodology, based on a "participatory model that } \\
\text { includes and commits, to all intervention stages, all } \\
\text { members of the organization; } \\
\text {-being free, without representing costs for organizations; }\end{array}$ \\
\hline
\end{tabular}




\begin{tabular}{l|l}
\hline - Recognition of the implementation & - The possibility of obtaining an external and independent \\
methodology as excellent. & diagnosis of problems; \\
& - Increased employee motivation; \\
& - Curiosity in learning more about the Q3. \\
\hline
\end{tabular}

Source: Own elaboration

\section{Correspondence between the results obtained in the diagnostic process and the expectations of the organizations}

In the Norte, the vast majority of organizations proved to be generally satisfied with the results of the diagnostic process, stating that it came to meet their expectations. In these cases, the respondents consider that the initial diagnostic process took place as planned having lived up to expectations and allowed the identification of the existing problems. Participation of employees in this process was highlighted. Some reservations have been identified in four organizations, related, overall, with the time of implementation (short and intensive), creating greater difficulty in the assimilation of the knowledge provided, as well as some delay in implementing certain measures. For 1 organization, the activities did not meet the dates set in the diagnosis.

In the Alentejo, it was found that in only one entity the results did not meet the organization's expectations. According to the collected impressions, this occurred because the institution expected a greater recognition of their individuality, considering that the methodology of diagnosis should present alternatives, have complementary instruments that could be applied "type plan B". For the rest, the expectations have been met, and the outcomes are representative and suited to the realities of the organizations.

\section{Degree of achievement of goals and level of dissatisfaction / satisfaction with the effects / results verified}

In this issue we sought to know the extent to which the objectives set in the diagnostic reports had been achieved (on a scale $0-100 \%$ ) as well as the degree of dissatisfaction / satisfaction with the effects / outcomes already achieved / realized (rated on a scale of likert of 4 points, where 1 is "not satisfied" and 4 for "very satisfied").

In the Norte, the degree of achievement of the goals has an average value of $69 \%$ ( 0 to $100 \%$ ), ranging between $14 \%$ and $100 \%$. Overall, the respondent organizations are satisfied with the effects of defined objectives (average of 3 ). In the Alentejo, the average level of achievement of the goals for organization varies widely. There were organizations with values lower than $20 \%$ and organizations with values greater than $80 \%$.

Assessing the degree of dissatisfaction / satisfaction with the implementation of the measures and the level of effects / verified results 
This question asked the respondents of the intervened institutions to assess the level of dissatisfaction / satisfaction with both the implementation of measures, and in terms of actual outcomes following the use / application of training (Table 8). This review was conducted considering a satisfaction scale ranging from "very unhappy (1)" and "very satisfied (4)."

Table 8: Overall satisfaction / dissatisfaction with the implementation of measures \& Level of satisfaction / dissatisfaction in terms of effects / results

\begin{tabular}{l|c|c}
\multicolumn{1}{c|}{ Measures } & Norte & Alentejo \\
\hline Total number of measures & 230 & 77 \\
\hline Satisfaction / dissatisfaction with the implementation of measures & 3,6 & 3,5 \\
\hline $\begin{array}{l}\text { Satisfaction / dissatisfaction in terms of effects / outcomes resulting } \\
\text { from implementation of the measures }\end{array}$ & 3,3 & 3,3 \\
\hline
\end{tabular}

Source: Own elaboration

In the case of the Norte, the responding organizations were quite satisfied with the performance of the implemented measures (average 3.6), as well as the effects produced (average 3.3). In Alentejo, average values are similar.

\section{General evaluation of the Q3 project - Degree of dissatisfaction / satisfaction with some aspects of the project}

In one of the questions the intervened organizations were asked to make a general evaluation of the project by indicating their level of dissatisfaction / satisfaction on various aspects of the Q3 project, considering the project as a whole [on a scale of 1 ("not satisfied") to 4 ("very satisfied")]. 15 variables were reviewed: the project methodology, diagnosis execution time, adequacy of diagnosis to the entity, the problems diagram, measures of the development plan, implementation schedule, involvement of management, involvement of middle management, involvement of employees, actions of promoters, activities of regional coordinators, role of liaison consultants, activities of trainers, adequacy of training and consulting actions and methods of training and consultancy (Table 9).

Table 9: Evaluation of general aspects of the Q3 project

\begin{tabular}{|c|c|c|c|c|c|c|c|c|c|c|c|c|c|c|c|}
\hline $\begin{array}{l}\text { General } \\
\text { aspects } \\
\text { of the } \\
\text { Q3 } \\
\text { project }\end{array}$ & 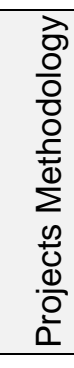 & 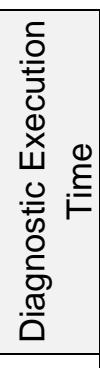 & 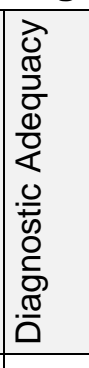 & 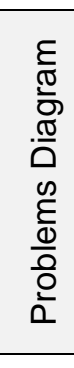 & 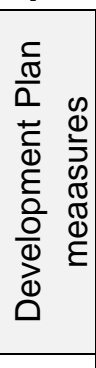 & 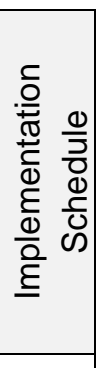 & 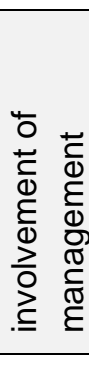 & 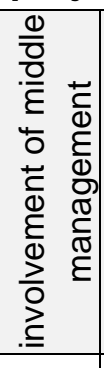 & 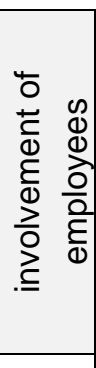 & 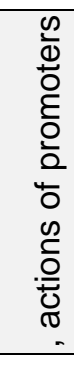 & 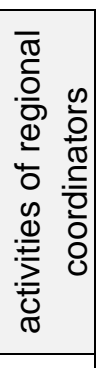 & 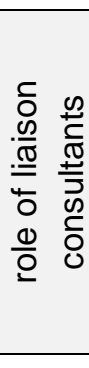 & 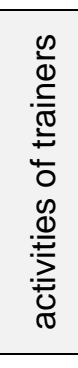 & 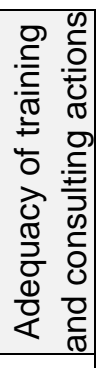 & 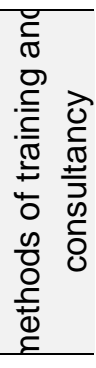 \\
\hline Jorte & 3,4 & 2,8 & 3 & 3,6 & 3,5 & 3,1 & 3 & 3,8 & 3,6 & 3,6 & 3 & 3,6 & 3,6 & 3, & 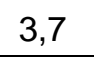 \\
\hline lentejo & 3,7 & 3,4 & 3,6 & 3,6 & 3,5 & 3,4 & 3,2 & 3,8 & 3,6 & 3,4 & 3,7 & 3,8 & 3,6 & 3 & 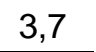 \\
\hline
\end{tabular}

Source: Own elaboration 
Overall, for the two regions, there are relatively high levels of satisfaction in most of the variables considered. The one that deserved a lower average rating was the "diagnosis execution time", especially for organizations in the Norte.

\section{Evaluation of the results achieved against initial expectations of the project (taken as a whole)}

When asked about the degree of satisfaction / dissatisfaction of the organizations given the results achieved with the project of Q3, the answers are quite positive. This degree was evaluated in order to allow four levels of response between "not happy (1)" and "very satisfied (4)."

Globally, intervened organizations of the Norte region shown to be satisfied and very satisfied with the Q3 project. Only two organizations reported little satisfaction with this assessment. Ten organizations from Alentejo reported being "very satisfied (4)" with the results from the application of Q3, for reasons relating to: the good organization of Q3, the achievement of objectives, the effectiveness of changes in the behaviour of employees, and the adequacy of the entity's needs. Only two organizations said they are "not satisfied (1)" with the Q3 project, for reasons that relate to poor participation in the training activities.

\section{Strengths and weaknesses}

To know the perceptions of the organizations surveyed about the strengths and weaknesses of the project proves to be extremely useful for its evaluation. Each organization could refer up to 3 strengths and weaknesses (Table 10).

Table 10: Strengths and weaknesses identified by organizations in both regions

\begin{tabular}{|c|c|c|}
\hline Regions & Strengths & Weaknesses \\
\hline 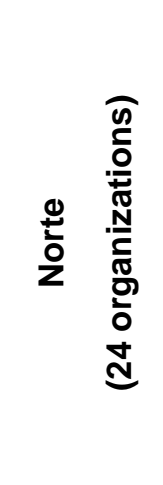 & $\begin{array}{l}\text { - Adjusting the training to needs; } \\
\text { - The various stages of intervention } \\
\text { methodology, as well as certain } \\
\text { characteristics of the same } \\
\text { methodology; } \\
\text { - Possibility to enhance results } \\
\text { (internal and external); and } \\
\text { - The possibility of an internal and } \\
\text { external evaluation; }\end{array}$ & $\begin{array}{l}\text { - The concentration of a large number of } \\
\text { formations in a short period of time; } \\
\text { - The duration of the various phases of the } \\
\text { project; }\end{array}$ \\
\hline
\end{tabular}




\begin{tabular}{l|l|l|l}
\hline & $\begin{array}{l}\text { - Trainers, LC and competent } \\
\text { coordinators; } \\
\text { - Importance of an external look and } \\
\text { suited to the needs; }\end{array}$ & $\begin{array}{l}\text { Difficulty in adjusting employees' time } \\
\text { availability with the implementation schedule; }\end{array}$ \\
- The need for more intensive monitoring by the \\
LC;
\end{tabular}

Source: Own elaboration

\section{Real changes}

Regarding the effects already produced and felt resulting from Q3, respondent organizations in both regions reported having already made changes in its organizational method.

Respondents are unanimous in referring improvements in interpersonal relationships of employees, associated with a greater predisposition to problem solving. They add, too, that there is a greater sense of responsibility and belonging to the institution, which has very positive consequences in their general functioning.

It is possible to add these changes in three key variables:

- Changes related to strategic dimensions of institutions (ex.: the attitude toward change, awareness of the problems, the importance of strategic planning and positioning and vision of the organizations in the future);

- Changes associated with how they manage human resources (in terms of leadership, motivation, communication, interaction teams, recruitment, interpersonal relationships, etc.); and

- Assistance in certification processes and resolution of operational problems.

\section{Impression left by Q3 in intervened organizations}

In both regions, the Q3 project left evident traces in the responding organizations. Extremely positive expressions / associations such as "excellent," "amazing on the positive side," "internal organization and creation of a sustainable system" were used, showing its usefulness for organizations that could benefit from this methodology. In the Norte region, two of the organizations showed some revealing expressions of discontent. 


\section{Conclusions}

\subsection{Main conclusions and recommendations}

The quality in the implementation of Q3 project is highly dependent on the various actors involved, since it is a methodology that needs, in order to maximize its potential, the strong involvement and participation of multiple stakeholders. Firstly, the main beneficiaries of Q3 methodology - members of the intervened organizations play a critical role in this process. The fact that they apply (and being selected) leads to the need of an accountability approach in co-creating changes in the way they work, both individually and in organizational terms. This stakeholder group is the best guarantee of project's execution quality. And to the assurance of that quality, liaison consultants, trainers, regional coordinators, promoters and monotoring organizations must act together in achieving common goals.

In a review of the available documentation of Q3 project's previous editions we verified that the opinion, relatively consensual, was that the project was very useful and that it added value in what concerns the qualification of employees of the institutions of the 3rd sector. In this edition of the project, in the Norte region, 1273 employees achieved qualification. In Alentejo, 989 employees were qualified.

The Q3 was a success in all its dimensions, from the diagnosis to the results obtained, from the action plans and the development of measures, the performance of trainers and consultants, to the overall coordination. The assessment made by the majority of managers and technical Staff on the Q3 methodology, on the work done by executors, coordinators and trainers, is very positive. The initial expectations were, in most cases, exceeded, in particular due to the good planning and implementation of Q3, the achievement of goals and the real changes in the behavior of employees.

Intervened organizations acknowledged the usefulness of the Q3 project. Overall, It can be stated that in the current edition, the project balance is very positive. The methodology has worked well, the degree of participation was high, expectations of organizations have been met and real changes at various levels were highlighted (eg, greater awareness of the problems, greater predisposition to change, greater motivation of human resources and improvement in interpersonal relationships).

The project has left indelible marks on the intervened organizations, nameely, by providing tools to support the management of the institutions and the rethinking of attitudes and behaviours, responsibility and increase knowledge. In summary, in general terms, the project's value is recognized. Here is the opinion of an internal facilitator that reflects this evaluation:

"We believe that these community based proximity projects, allow us to leverage many processes that alone we could not, nor do we have the ability to do so. We consider extremely important that there be groups, corporate or institutional, that allow this support to the institutions, in order to provide better services and greater sustainability".

Reflecting on what was said, one can explicitly identify the various conclusions, which 
allude to lessons / recommendations to withdraw:

- In the various editions of the program there has been no difficulty in capturing organizations to participate in the project. However, disclosure and dissemination should continue to be considered as strategic, not only to seek the participation of a wider range of 3rd sector institutions that could benefit from the program but also to validate and allow the recognition by other important stakeholders. Various communication tools have been used, both on a specific level (dissemination, through various means done by promoters and intervened organizations and even by other partner organizations) and on a institutional level (disclosure web page and the facebook social network). In the latter case a larger communicative effort could be done to expand the scope of the project, its results and contributions over the various editions. After all, the strengthening of Q3 brand appears as a fundamental element of a wider recognition of the program whose merit is properly recognized by all parties.

- Performing a good selection of institutions is critical to the project' success. It suggests some caution in this variable, and there should be a rigorous clarification of programmatic lines of $\mathrm{Q} 3$ in order to not disappoint the created expectations. The leaders of the institutions must be aware of the selection requirements and the conditions to enhance project success in their institutions. Strengthening the critical need for involvement and participation of all stakeholders in this process is a prerequisite to leverage the benefits of the project. Based on the accumulated experience of the involved partners, as well as on indicators / targets/ benchmarking, potential maladjusted selections should be avoided.

- It is desirable to continue and strengthen the "action per measure" for the diagnosis analysis as well as the development plan, seeking to create some flexibility in certain procedures. The issue of adaptability to the needs of institutions is a highly recognized element by those involved.

- On the other hand, it would be useful to disseminate by promoter the problems, measures and the observed good practices, in presentation/demonstration sessions. A greater inter-institutional contact was suggested by several organizations in terms of sharing common experiences and learning outcomes and processes.

- Consultants and organizations recognized, as a distinctive excelent aspect of Q3, the fact that it was free and needs-adjusted training. However, we suggest the need to continue to maintain and strengthen this nature of needs-adjustment in implementing measures to the specificities of institutions. As stated earlier, the participation of organizations in this process is critical. The intervened organizations should be aware that they are co-responsible for the success of the intervention, so a strong commitment from everyone involved is needed. This implies that all should "work" the training outcomes both during and after training sessions.

- The question of the difficulties in achieving the desired trainers to specific interventions was also placed both by LC and by IF.

- The measurement of results is relatively difficult in the short term, "a large part of the 
results do not occur in the short term and these results are dependent on the internal context which promote its implementation and consolidation." As already mentioned, the evaluation team believes that the Q3 project should invest in post-implementation monitoring. It recognized the need for a follow-up that allows the support of organizations in implementing the acquired tools and enhances the work done.

- Comments on the need to simplify the bureaucratic burden of Q3 are repeatedly mentioned. On the other hand, the simplification of processes and the adequacy of Q3 to collectivities (cultural, sports, recreational) are critical in order to increase the degree of success of Q3 to the 3rd sector. This goal requires some a flexibility (due to the different natures and various dimensions) that the program currently does not have.

\subsection{Contributions and limitations}

This type of projects in addition to specific objectives inherent to the particularities of the methodology used, should ultimately aim to contribute to the growth and increasing sustainability of the sector in question (and the organizations that comprise it) regarding several levels of analysis. For this to happen, projects that will deepen the knowledge apprehended in terms of the functioning of different types of organizations and their qualification processes prove to be extremely useful.

In fact, regarding the literature related to the sector, there are relatively few studies in the national context that address these issues. Being a project with a national scope, and given the number of organizations (and people) that benefit from this methodology, we think we met the conditions to better understand the mode of operation of such organizations, particularly when the actors, themselves, express the problems and challenges they face. The contribution to the qualification of the human capital of these organizations is evident.

This study shows the potential of Q3 approach to the qualification of the 3rd sector organizations. The methodology of training- participatory action, implemented by consultants and trainers with process facilitation and management skills, as well as sensitivity and experience in non-profit organizations, is an efficient and effective tool for organizational change, adapted to different circumstances. However, as pointed out, its success depends, to a large extent, on their appropriation by the organizations, through managers, technical staff and other employee's commitment and participation. Moreover, it seems clear, from the cases analyzed here, the state of need and awareness of the urgency for change in organizations, which is also a highly prominent factor.

One limitation of this study relates to the number of stakeholders involved in the various inquiry stages to monitor and evaluate the Q3 project, which could have included both trainers and employees of the institutions (other than FI and elements of direction of the institutions) and the promoters and even the customers of intervened organizations. 
A different aspect relates to the necessary measuring of results over time. Some time after completion of the intervention it would be desirable to carry out evaluation work, since the effects of this action will, most likely, be more visible. Performing this assessment immediately after the completion of the project, presents some difficulties to the intervened organization to fully assess the obtained results.

\section{References}

ALMEIDA, V. (2007). Terceiro Sector e Economia do Conhecimento, Interaç̧ões. 2007, 11, 55-83.

DEFOURRNY, J. (2001). Introduction, In Carlo Borzaga e Jacques Defourny (eds.), The Emergence of Social Enterprise. Londres e Nova lorque: Routledge, 1-28.

EFQM, European Foundation for Quality Management, 2012, retrieved from http://www.efqm.org/theefqm-excellence-model.

GEP/MTSS (2008), Séries Estatísticas. Lisboa: Gabinete de Estratégia e Planeamento,

Governamentais para o Desenvolvimento, em Portugal. Dissertação de Mestrado.

HESPANHA, P. et al. (2000). Entre o Estado e o Mercado. As fragilidades das instituições de protecção social em Portugal. Coimbra: Quarteto.

HORN, F. (2003). Nouveaux Standards et Logiciels Libres, un espace d'innovations à but non lucrative?, In Philippe Mustar et Hervé Penan (dir.), Encyclopédie de L'Innovation. Paris: Economica, 555-577.

LÉVESQUE, BENOÎT (2006). Le potentiel d'innovation et de transformation de l'économie sociale: quelques éléments de problématique. Cahiers du Centre de recherche sur les innovations sociales (CRISES), Collection Études théoriques - no ET0604.

PARENTE, C. (2012). Qualified Employment in the Third Sector in Portugal. Voluntas. 2012 23:257276.

REBOLA, E (2004). Funcionamento e sustentabilidade das organizações não governamentais para o desenvolvimento, em Portugal. Dissertação de Mestrado. Universidade Técnica de Lisboa. Instituto Superior de Economia e Gestão.

REGO, R. (2010). A Profissionalização do Terceiro Sector: o caso do associativismo. In J. Freire, \& P. P. Almeida, Trabalho Moderno, Tecnologia e Organizações (pp. 153-178). Porto: Afrontamento. 